\title{
Application of commercial arbuscular endomycorrhizal fungal inoculants to the establishment of micropropagated grapevine rootstock and pineapple plants
}

\author{
P Lovato *, JP Guillemin, S Gianinazzi **
}

INRA-CNRS, laboratoire de Phytoparasitologie, Station de génétique et d'amélioration des plantes, INRA, BV 1540, 21034 Dijon Cédex, France

(COST Meeting, 21-23 May 1992, Dijon, France)

\begin{abstract}
Summary - Commercial inoculants of arbuscular mycorrhizal (AM) fungi were tested on 2 plant species. Micropropagated grapevine plantlets were grown in a greenhouse and inoculated with 2 commercial inoculants applied to the growth substrata. No physical or chemical effect of the sterilized inoculants was observed. Mycorrhizal grapevine plants showed a 3-fold increase in shoot growth as compared to control plants. Almost all root pieces were infected and the percentage of root length showing presence of the mycorrhizal fungus was $\approx 30 \%$. The same inoculants were compared to efficient fungal isolates in micropropagated pineapple plants of 3 varieties grown in a controlled environment chamber with simulated tropical conditions. Plants grew better in acid than in alkaline soil, and Glomus sp (isolate LPA21) was more efficient in acid soil than both commercial inoculants. An increased inoculant dose from $1 \%$ to $3 \%$ sometimes caused an increase in root infection with increases or decreases in plant growth depending on pineapple variety or type of inoculum used. One inoculant tended to improve growth in alkaline soil, while another was more efficient in acid soil. The implications of the use of these products are discussed.
\end{abstract}

grapevine / pineapple / micropropagation / arbuscular endomycorrhiza / plant growth / infection development

\begin{abstract}
Résumé - Utilisation d'inoculums commerciaux de champignons endomycorhiziens pour l'établissement de porte-greffe de vigne et de plantes d'ananas micropropagés. Des inocula commerciaux de champignons endomycorhizogènes à arbuscules ont été éprouvés sur 2 plantes micropropagées, la vigne et l'ananas. Les porte-greffes de vignes micropropagés sont infectés avec 2 inoculums commerciaux mélangés aux substrats de culture et placés en serre. L'apport des inoculums commerciaux stérilisés n'a pas affecté la croissance des vitroplants écartant les effets chimiques et physiques de ces inocula. La croissance des vignes mycorhizées a été 3 fois supérieure à celle des plantes non-mycorhizées. Presque toutes les racines ont été infectées et le développement de l'infection est de l'ordre de $30 \%$. Ces mêmes inoculums ont été comparés à des isolats endomycorhizogènes capables de stimuler la croissance des trois variétés de vitroplants d'ananas. Ces plantes présentaient une meilleure croissance dans le sol acide que dans le sol alcalin. Dans le sol acide, l'isolat de Glomus sp. (LPA21) est plus efficient sur la croissance des ananas que les inoculums commerciaux. L'augmentation des doses d'inoculums de $1 \%$ à $3 \%$ est souvent liée à une élévation de l'infection endomycorhizienne. Par contre, les effets sur la croissance varient selon les combinaisons plantehôte / inoculum utilisées. Un des inoculums commerciaux semble avoir été plus performant sur la croissance des vitroplants d'ananas dans le sol alcalin, tandis que l'autre inoculum l'était plus dans le sol acide. Les conséquences de l'utilisation de ces produits sont discutées.
\end{abstract}

vigne / ananas / micropropagation / endomycorhize à arbuscule / croissance / infection endomycorhizienne

\footnotetext{
* On leave from the Universidade Federal de Santa Catarina, Florianópolis, SC, Brazil

** Correspondence and reprints
} 


\section{INTRODUCTION}

Mycorrhizas are mutualistic associations occurring between most plant species and several groups of fungi. The most common type is one in which the fungal symbiont colonizes root cells to form special structures termed arbuscules and, in some cases vesicles, and for this reason they are called arbuscular endomycorrhizas (AM). These symbiotic associations benefit plants essentially by improving mineral nutrition, water uptake, hormone production or resistance to root pathogens and pests (Gianinazzi et al, 1982; Harley and Smith, 1983). They occur naturally in most situations, but plant production systems involving soil disinfection, artificial substrata and plant micropropagation tend to eliminate them, which means that they are often absent from horticultural plants, and consequently appropriate fungi must be introduced by inoculation.

Inoculation of AM fungi to nursery plants has been proven both necessary and feasible (Menge, 1977), and it has been extended to micropropagated plants (Kiernan et al, 1984; Ravolanirina et al, 1989; Gianinazzi et al, 1990; Guillemin et al, 1991). However, inoculation has generally been performed at the experimental level (Blal and Gianinazzi-Pearson, 1989) or at a pre-commercial stage (Gianinazzi et al, 1990). Inoculants have already been commercialized (Wood, 1987; Sieverding, 1991) but have encountered some setbacks because their use has not become common practice. The use of commercial inoculants requires precise information on their quality, the essential parameters being infection and growth-promoting potentials. Furthermore, it is also necessary to determine efficient procedures and dose rates that can be recommended for promoting growth of individual plant species. In the present experiments, 2 commercial inoculants of different origin have been tested for their efficiency in infecting and promoting growth of grapevine rootstock and pineapple microplants.

\section{MATERIALS AND METHODS}

\section{Experiment 1}

Micropropagated plantlets of grapevine rootstock $\mathrm{SO}_{4}$ 102 were multiplied in Murashighe and Skoog (MS) modified growth medium (Carre et al, 1979). At the stage of 2 root initials, they were transferred to pots $\left(0.4 \mathrm{dm}^{3}\right)$ containing $400 \mathrm{~g} \gamma$-irradiated (10 Gy) clay loam soil ( $\mathrm{pH} 7.8)$. Inoculation treatments were as follows: sterilized soil (control); granular inoculant from Agricultural Genetics Company (AGC, UK) applied at a $1 \%(w w)$ rate (AGC $1 \%$ ); the same inoculant at $5 \%$ (AGC $5 \%$ ); sterilized AGC granulated inoculant at $1 \%$ (sterile AGC 1\%); the same sterilized inoculant at 5\% (sterile AGC 5\%); granular inoculant from Phytotec (Belgium) at $1 \%$ (Phytotec). The sterilized inoculant treatments were included to determine whether the physical and chemical nature of the inoculant could influence plant growth. Six replicate microplants per treatment were transferred to individual pots according to the procedure of Ravolanirina et al (1989) and acclimatized in a growth chamber $\left(300 \mu \mathrm{E} . \mathrm{s}^{-1} \mathrm{~m}^{-2}, 26-\right.$ $24^{\circ} \mathrm{C}$, 16-h day, $60-80 \%$ relative humidity) for $10 \mathrm{~d}$ before transfer to a temperature-controlled $\left(20-25^{\circ} \mathrm{C}\right)$ greenhouse. Distilled water was added to each pot daily, and each week $20 \mathrm{ml}$ of Long Ashton solution (Hewitt, 1966) with P diluted 1:10. Plants were harvested after $60 \mathrm{~d}$ (July-August) to determine shoot and root fresh mass and shoot dry mass. Roots were cleared and stained with trypan blue (Phillips and Hayman, 1970) and infection was evaluated according to Trouvelot et al (1986), where the parameter $\mathrm{F} \%=$ percentage of root pieces with fungal infection and $M \%=$ evaluation of the volume of the root cortex occupied by the fungus.

\section{Experiment 2}

The same commercial granular inoculants from AGC and Phytotec were tested for their effect on 3 pineapple varieties (Queen Tahiti, Smooth Cayenne (clone $\mathrm{CY}_{0}$ ), Spanish) in acid ( $\mathrm{pH} 5.0$ ) and alkaline ( $\mathrm{pH}$ 8.0) soils. Their efficiency was compared to Glomus $\mathrm{sp}$ (isolate LPA21) in the acid soil and to Glomus intraradices (isolate LPA8) in alkaline soil for the 3 varieties. These plant-fungus-soil combinations have previously been shown to be efficient (Guillemin et al, 1992).

The pineapple microplants were inoculated in trays (30 plants per tray) containing $1.5 \mathrm{~kg}$ soil-gravel (11) mix during the post vitro acclimatization period (Guille$\min$ et al, 1991). The commercial inoculants were applied at $1 \%$ and $3 \%$ (ww). For each tray, isolate inoculum comprised $3 \mathrm{~g}$ freshly chopped endomycorrhizal roots of Tephrosia ehlenbergiana for isolate LPA21 and of Allium cepa L for isolate LPA8. After 1 month, the pineapple plantlets were individually transplanted to pots containing $400 \mathrm{~g}$ soil-gravel mix (1:1). Plants were raised under simulated tropical growth room conditions $\left(300 \mu \mathrm{E} . \mathrm{s}^{-1} \mathrm{~m}^{-2}, 26-24{ }^{\circ} \mathrm{C}, 16\right.$-h day and $60-$ $80 \%$ relative humidity). Distilled water was added to each pot daily and twice weekly $20 \mathrm{ml}$ Hoagland No 2 solution (Hoagland and Arnon, 1950) without phosphate. Each treatment comprised 5 replications. After 3 months, plant growth was evaluated by leaf number, leaf area, shoot and root fresh mass and shoot dry mass. 
Infection development (M\%) was assessed as described above, and arbuscule frequency in the root cortex $(A \%)$ was also evaluated.

\section{RESULTS}

\section{Experiment 1}

The application of commercial inoculants was beneficial to the establishment and growth of micropropagated grapevine plantlets. There was a significant positive effect on the growth of the micropropagated grapevine rootstock which showed a 3-fold increase in root and shoot growth (table I). The treatments with the sterilized substrata showed no significant difference from the uninoculated control.

Infection level was expressed by 2 parameters (table I). The first, F\%, showed that $>90 \%$ of the root pieces examined were infected, indicating a high soil receptivity vis-à-vis the inoculants. The second parameter, $M \%$, expressed the intensity of the infection developing within root tissues. With the AGC inoculant, $40 \%$ of the root length was mycorrhizal, while this parameter attained $\approx$ $30 \%$ for the Phytotec inoculant. There was no difference between the application rates of 1 or $5 \%$, which shows that the inoculants had an infection potential high enough to promote growth at the lowest concentration used.

\section{Experiment 2}

Growth of pineapple plants differed markedly in acid and alkaline soils, so these will be examined separately. Plant growth and endomycorrhizal infection parameters were generally lower in alkaline than in acid soil.

In alkaline soil, inoculation of plants of the Queen Tahiti variety (table II) caused better growth as expressed by leaf area and shoot fresh and dry mass than that of uninoculated plants, but there were no significant differences among the inocula. No significant differences were observed in root fresh mass, although plants inoculated with AGC inoculants tended to have lower root fresh mass than the other treatments. For infection parameters, AGC inoculant caused a higher frequency of arbuscules than the other inoculi.

For Smooth Cayenne variety plants (table III), AGC inoculant showed the best performance expressed in terms of leaf area, shoot fresh mass and dry mass. There were smaller differences in root fresh mass, although the same tendency was found. The highest levels of infection were obtained with AGC inoculant and $G$ intraradices. The striking feature with this variety was that plants with the best growth had the highest levels of infection intensity and arbuscule frequency.

For the Spanish variety (table IV), differences among inocula in effects on shoot fresh and dry mass and root fresh mass were less significant. However, there was a clear tendency for the AGC inoculant to promote increases in leaf area. The AGC inoculant also resulted in the highest levels of infection intensity and arbuscule frequency in this variety, and these were significantly greater in comparison to plants inoculated with the Phytotec inoculant. These results clearly show that the AGC inoculant promoted better growth of pineapple plants in the alkaline soil than the Phytotec inoculant.

Table I. Shoot and root fresh mass, shoot dry mass and endomycorrhizal infection (frequency of infection ( $\mathrm{F} \%$ ) and intensity of infection (M\%)) of grapevine rootstock $\mathrm{SO}_{4} 102$ growing in $\gamma$-irradiated alkaline soil alone (control), or with addition of sterile or non-sterile AGC inoculant at 2 application rates or Phytotec inoculant at $5 \%$ rate.

\begin{tabular}{|c|c|c|c|c|c|c|}
\hline & \multirow[t]{2}{*}{ Control } & \multicolumn{2}{|c|}{ Sterile AGC } & \multicolumn{2}{|c|}{$A G C$} & \multirow[t]{2}{*}{ Phytotec } \\
\hline & & $1 \%$ & $5 \%$ & $1 \%$ & $5 \%$ & \\
\hline Shoot fresh mass & $1.95^{b}$ & $1.37^{\mathrm{b}}$ & $2.42^{b}$ & $7.25^{\mathrm{a}}$ & $6.24^{a}$ & $7.36^{a}$ \\
\hline Root fresh mass & $2.17^{b}$ & $1.67^{\mathrm{b}}$ & $3.50^{b}$ & $7.57^{a}$ & $7.04^{a}$ & $7.38^{a}$ \\
\hline Shoot dry mass & $0.57^{b}$ & $0.39^{b}$ & $0.75^{b}$ & $2.02^{a}$ & $1.79^{a}$ & $1.99^{\mathrm{a}}$ \\
\hline Frequency of infection (F\%) & & & & $93^{a}$ & $83^{a}$ & $89 a$ \\
\hline Intensity of infection (M\%) & & & & $39 a$ & $37^{a}$ & $28^{a}$ \\
\hline
\end{tabular}


Table II. Leaf area, shoot and root fresh mass, shoot dry mass and endomycorrhizal infection (intensity of infection $(\mathrm{M} \%)$ and arbuscule frequency $(\mathrm{A} \%)$ ) of plants of the Queen Tahiti pineapple variety; uninoculated and inoculated with Glomus intraradices or commercial inoculants (AGC $1 \%$ or $3 \%$, Phytotec $1 \%$ or $3 \%$ ) in an alkaline soil.

\begin{tabular}{|c|c|c|c|c|c|c|c|}
\hline & & \multirow[t]{2}{*}{ Uninoculated } & \multirow{2}{*}{$\begin{array}{c}\text { Glomus } \\
\text { intraradices }\end{array}$} & \multicolumn{2}{|c|}{$A G C$} & \multicolumn{2}{|c|}{ Phytotec } \\
\hline & & & & $1 \%$ & $3 \%$ & $1 \%$ & $3 \%$ \\
\hline Leaf area & $\left(\mathrm{cm}^{2}\right)$ & $61.1^{b}$ & $99.9^{a}$ & $145.1^{a}$ & $141.9^{a}$ & $125.4^{a}$ & $145.4^{\mathrm{a}}$ \\
\hline Shoot fresh mass & (g) & $4.26^{b}$ & $8.02^{a}$ & $10.32^{\mathrm{a}}$ & $8.91^{a}$ & $8.10^{\mathrm{a}}$ & $9.59^{\mathrm{a}}$ \\
\hline Root fresh mass & (g) & $0.83^{a}$ & $1.28^{a}$ & $1.07^{a}$ & $0.98^{a}$ & $1.43^{a}$ & $1.61^{a}$ \\
\hline Shoot dry mass & (g) & $0.51^{b}$ & $0.72^{\mathrm{a}}$ & $1.17^{a}$ & $1.10^{\mathrm{a}}$ & $0.97^{a}$ & $1.12^{\mathrm{a}}$ \\
\hline Intensity of infection & $(\mathrm{M} \%)$ & $0^{b}$ & $56^{a}$ & $63^{a}$ & $55^{a}$ & $36^{a}$ & $46^{a}$ \\
\hline Arbuscule & $(\mathrm{A} \%)$ & $\mathrm{O}^{\mathrm{c}}$ & $24^{a b}$ & $35^{a}$ & $33^{a}$ & $18^{b}$ & $28^{a b}$ \\
\hline
\end{tabular}

Values in each line followed by different letters are significantly different $(P<0.05)$.

Table III. Leaf area, shoot and root fresh mass, shoot dry mass and endomycorrhizal infection (intensity of infection $(\mathrm{M} \%)$ and arbuscule frequency $(\mathrm{A} \%)$ ) of plants of the Smooth Cayenne pineapple variety, uninoculated and inoculated with Glomus intraradices or commercial inoculants (AGC $1 \%$ or $3 \%$, Phytotec $1 \%$ or $3 \%$ ) in an alkaline soil.

$$
\begin{gathered}
\text { Uninoculated Glomus } \\
\text { intraradices }
\end{gathered}
$$

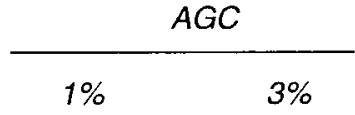

$\begin{array}{lcc}\left(\mathrm{cm}^{2}\right) & 50.7^{c} & 120.6^{\mathrm{b}} \\ (\mathrm{g}) & 3.45^{\mathrm{c}} & 9.19^{\mathrm{b}} \\ (\mathrm{g}) & 0.48^{\mathrm{b}} & 0.90^{\mathrm{ab}} \\ (\mathrm{g}) & 0.43^{\mathrm{c}} & 0.97^{\mathrm{b}}\end{array}$

$160.2^{a b}$
$12.34^{a b}$
$1.15^{a b}$
$1.31^{a b}$

$\begin{array}{ll}0^{d} & 64^{\mathrm{ab}} \\ 0^{\mathrm{d}} & 35^{\mathrm{b}}\end{array}$

$\mathrm{o}^{\mathrm{d}}$

$\begin{array}{ll}0^{d} & 64^{a b} \\ 0^{d} & 35^{b}\end{array}$

$69^{a b}$

$48^{\mathrm{a}}$

\begin{tabular}{cr}
\multicolumn{3}{c}{ Phytotec } \\
\hline $1 \%$ & $3 \%$
\end{tabular}

Intensity of infection $(\mathrm{M} \%)$
Arbuscule frequency $(\mathrm{A} \%)$

$\begin{array}{ccc}208.0^{\mathrm{a}} & 109.4^{\mathrm{b}} & 113.6^{\mathrm{b}} \\ 16.11^{\mathrm{a}} & 8.05^{\mathrm{b}} & 10.08^{\mathrm{b}} \\ 1.41^{\mathrm{ab}} & 1.40^{\mathrm{ab}} & 1.68^{\mathrm{a}} \\ 1.64^{\mathrm{a}} & 0.86^{\mathrm{b}} & 1.14^{\mathrm{b}} \\ & & \\ 74^{\mathrm{a}} & 20^{\mathrm{c}} & 47^{\mathrm{b}} \\ 51^{\mathrm{a}} & 5^{\mathrm{c}} & 13^{\mathrm{c}}\end{array}$

Values in each line followed by different letters are significantly different $(P<0.05)$.

In the acid soil, responses to the inocula varied with the plant variety. The Queen Tahiti variety (table V) showed best growth when inoculated with Glomus sp (LPA21). In general, plants treated with the commercial inoculants had growth parameters which, except for root fresh mass, did not differ significantly from those of uninoculated plants. There was an important difference in the infectivity of the different inocula in this variety. Infection levels were highest with Glomus sp (LPA21) and lowest for the Phytotec inoculant at $1 \%$.

The Glomus sp (LPA21) inoculum also promoted best growth in plants of the Smooth Cay- enne variety (table $\mathrm{VI}$ ), and of the 2 commercial products, the Phytotec inoculant tended to promote better growth than that from AGC. There was, however, no significant difference in infection parameters among the commercial inoculants, although these were lower than those observed in plants infected by Glomus sp (LPA21).

Highest values in shoot fresh and dry mass as well as leaf area were obtained in Spanish variety plants (table VII) by inoculation with Glomus sp (LPA21) or Phytotec at $3 \%$. This was not related to the level of infection, which was similar for the commercial inoculants but, as for the other 2 varieties, it was highest in Glomus sp (LPA21). 
Table IV. Leaf area, shoot and root fresh mass, shoot dry mass and endomycorrhizal infection (intensity of infection $(\mathrm{M} \%)$ and arbuscule frequency $(\mathrm{A} \%)$ ) of plants of the Spanish pineapple variety; uninoculated and inoculated with Glomus intraradices or commercial inoculants (AGC $1 \%$ or $3 \%$, Phytotec $1 \%$ or $3 \%$ ) in an alkaline soil.

\begin{tabular}{|c|c|c|c|c|c|c|c|}
\hline & & \multirow[t]{2}{*}{ Uninoculated } & \multirow{2}{*}{$\begin{array}{c}\text { Glomus } \\
\text { intraradices }\end{array}$} & \multicolumn{2}{|c|}{$A G C$} & \multicolumn{2}{|c|}{ Phytotec } \\
\hline & & & & $1 \%$ & $3 \%$ & $1 \%$ & $3 \%$ \\
\hline Leaf area & $\left(\mathrm{cm}^{2}\right)$ & $106.4^{c}$ & $130.3^{b c}$ & $231.2^{\mathrm{a}}$ & $219.7^{a b}$ & $181.5^{a b c}$ & $169.5^{\mathrm{abc}}$ \\
\hline Shoot fresh mass & (g) & $6.80^{b}$ & $9.88^{a b}$ & $15.98^{a}$ & $14.36^{a}$ & $11.75^{\mathrm{ab}}$ & $10.48^{a b}$ \\
\hline Root fresh mass & (g) & $0.83^{a}$ & $1.82^{a}$ & $1.53^{a}$ & $1.74^{a}$ & $1.20^{\mathrm{a}}$ & $1.61^{a}$ \\
\hline Shoot dry mass & (g) & $0.78^{b}$ & $1.24^{\mathrm{ab}}$ & $1.77^{\mathrm{a}}$ & $1.60^{a b}$ & $1.47^{a b}$ & $1.33^{a b}$ \\
\hline Intensity of infection & $(\mathrm{M} \%)$ & $0^{c}$ & $51^{a}$ & $63^{a}$ & $66^{a}$ & $19^{b}$ & $15^{b}$ \\
\hline Arbuscule frequency & $(A \%)$ & $\mathrm{O}^{\mathrm{d}}$ & $23^{b}$ & $37^{a}$ & $39 a$ & $4^{c}$ & $3^{c}$ \\
\hline
\end{tabular}

Values in each line followed by different letters are significantly different $(P<0.05)$.

Table V. Leaf area, shoot and root fresh mass, shoot dry mass and endomycorrhizal infection (intensity of infection $(\mathrm{M} \%)$ and arbuscule frequency $(\mathrm{A} \%)$ ) of plants of the Queen Tahiti pineapple variety; uninoculated and inoculated with Glomus sp or commercial inoculants (AGC $1 \%$ or $3 \%$, Phytotec $1 \%$ or $3 \%$ ) in an acid soil.

\begin{tabular}{|c|c|c|c|c|c|c|c|}
\hline & & \multirow[t]{2}{*}{ Uninoculated } & \multirow[t]{2}{*}{ Glomus $s p$} & \multicolumn{2}{|c|}{$A G C$} & \multicolumn{2}{|c|}{ Phytotec } \\
\hline & & & & $1 \%$ & $3 \%$ & $1 \%$ & $3 \%$ \\
\hline Leaf area & $\left(\mathrm{cm}^{2}\right)$ & $116.9^{b}$ & $423.6^{a}$ & $244.8^{b}$ & $242.7^{b}$ & $279.3^{b}$ & $195.9^{b}$ \\
\hline Shoot fresh mass & (g) & $8.38^{b}$ & $32.76^{a}$ & $18.54^{\mathfrak{b}}$ & $17.78^{\mathrm{b}}$ & $19.39^{b}$ & $13.99^{b}$ \\
\hline Root fresh mass & (g) & $0.95^{\mathrm{b}}$ & $3.10^{\mathrm{a}}$ & $2.71^{\mathrm{a}}$ & $2.27^{a}$ & $2.78^{a}$ & $1.78^{a b}$ \\
\hline Shoot dry mass & (g) & $1.04^{\mathrm{b}}$ & $3.38^{a}$ & $2.01^{a b}$ & $2.01^{\mathrm{ab}}$ & $2.23^{a b}$ & $1.57^{b}$ \\
\hline Intensity of infection & $(M \%)$ & $0^{d}$ & $89^{a}$ & $46^{b}$ & $47^{b}$ & $13^{c}$ & $37^{b}$ \\
\hline Arbuscule frequency & $(A \%)$ & $\mathrm{O}^{\mathrm{c}}$ & $57^{a}$ & $17^{b}$ & $20^{b}$ & $8^{b}$ & $10^{b}$ \\
\hline
\end{tabular}

Values in each line followed by different letters are significantly different $(P<0.05)$.

Table VI. Leaf area, shoot and root fresh mass, shoot dry mass and endomycorrhizal infection (intensity of infection $(\mathrm{M} \%)$ and arbuscule frequency $(\mathrm{A} \%)$ ) of plants of the Smooth Cayenne pineapple variety; uninoculated and inoculated with Glomus sp or commercial inoculants (AGC $1 \%$ or $3 \%$, Phytotec $1 \%$ or $3 \%$ ) in an acid soil.

\begin{tabular}{|c|c|c|c|c|c|c|c|}
\hline & & \multirow[t]{2}{*}{ Uninoculated } & \multirow[t]{2}{*}{ Glomus $s p$} & \multicolumn{2}{|c|}{$A G C$} & \multicolumn{2}{|c|}{ Phytotec } \\
\hline & & & & $1 \%$ & $3 \%$ & $1 \%$ & $3 \%$ \\
\hline Leaf area & $\left(\mathrm{cm}^{2}\right)$ & $133.3^{b}$ & $318.8^{a}$ & $204.8^{a b}$ & $132.4^{b}$ & $305.1^{a}$ & $220.1 \mathrm{ab}$ \\
\hline Shoot fresh mass & (g) & $10.21^{b}$ & $27.07^{a}$ & $17.62^{\mathrm{ab}}$ & $9.96^{b}$ & $26.10^{\mathrm{a}}$ & $19.00^{a b}$ \\
\hline Root fresh mass & (g) & $1.50^{\mathrm{b}}$ & $2.67^{a b}$ & $2.01^{b}$ & $1.31^{\mathrm{b}}$ & $3.51^{a}$ & $2.39^{a b}$ \\
\hline Shoot dry mass & (g) & $1.04^{c}$ & $3.29^{a}$ & $1.76^{\mathrm{bc}}$ & $1.05^{\mathrm{c}}$ & $2.67^{a b}$ & $1.91^{b c}$ \\
\hline Intensity of infection & $(M \%)$ & $o^{c}$ & $87^{a}$ & $42^{b}$ & $36^{b}$ & $29 b$ & $51^{b}$ \\
\hline Arbuscule frequency & $(A \%)$ & $0^{c}$ & $65^{a}$ & $25^{b}$ & $15^{b}$ & $18^{b}$ & $24^{b}$ \\
\hline
\end{tabular}


Table VII. Leaf area, shoot and root fresh mass, shoot dry mass and endomycorrhizal infection (intensity of infection $(\mathrm{M} \%)$ and arbuscule frequency $(\mathrm{A} \%)$ ) of plants of the Spanish pineapple variety; uninoculated and inoculated with Glomus sp or commercial inoculants (AGC $1 \%$ or $3 \%$, Phytotec $1 \%$ or $3 \%$ ) in an acid soil.

\begin{tabular}{|c|c|c|c|c|c|c|c|}
\hline & & \multirow[t]{2}{*}{ Uninoculated } & \multirow[t]{2}{*}{ Glomus sp } & \multicolumn{2}{|c|}{$A G C$} & \multicolumn{2}{|c|}{ Phytotec } \\
\hline & & & & $1 \%$ & $3 \%$ & $1 \%$ & $3 \%$ \\
\hline Leaf area & $\left(\mathrm{cm}^{2}\right)$ & $160.6^{b}$ & $346.7^{a}$ & $226.1^{\mathrm{ab}}$ & $251.1^{\mathrm{ab}}$ & $279.2^{\mathrm{ab}}$ & $384.2^{a}$ \\
\hline Shoot fresh mass & (g) & $10.02^{b}$ & $29.21^{a}$ & $15.63^{b}$ & $17.93^{b}$ & $19.51^{b}$ & $30.93^{a}$ \\
\hline Root fresh mass & (g) & $1.40^{\mathrm{b}}$ & $2.55^{\mathrm{ab}}$ & $2.34^{a b}$ & $2.49^{a b}$ & $2.73^{a b}$ & $4.01^{a}$ \\
\hline Shoot dry mass & (g) & $0.72^{\mathrm{C}}$ & $2.69^{a b}$ & $1.81^{b}$ & $1.92^{\mathrm{b}}$ & $2.18^{b}$ & $3.29^{a}$ \\
\hline Intensity of infection & $(\mathrm{M} \%)$ & $o^{c}$ & $87^{a}$ & $35^{b}$ & $39 b$ & $30^{\mathrm{b}}$ & $34^{b}$ \\
\hline Arbuscule frequency & $(\mathrm{A} \%)$ & $0^{c}$ & $69^{a}$ & $12^{b}$ & $22^{b}$ & $10^{\mathrm{b}}$ & $17^{b}$ \\
\hline
\end{tabular}

Values in each line followed by different letters are significantly different $(P<0.05)$.

There were no clear-cut doses for the commercial inoculants. In the alkaline soil, increasing the dose of the AGC inoculant caused a relative increase in the growth of Smooth Cayenne plants (table III). In the acid soil, increasing the dose of Phytotec caused poorer growth of the Queen Tahiti and Smooth Cayenne varieties (tables $\mathrm{V}$ and $\mathrm{VI}$ ), but caused an increase in growth of plants of the Spanish variety (table VII). Furthermore, the $3 \%$ dose of the AGC inoculant caused a decrease in shoot mass and in leaf area of Smooth Cayenne variety plants to values similar to uninoculated controls (table VII).

\section{DISCUSSION}

The absence of differences in plant growth between the control grapevine plants and those receiving the $\gamma$-irradiated inoculant showed that positive effects were due to the inoculum, and that there was no chemical or physical effect of these substrata on plant growth. However, it should be kept in mind that the positive effects may have been due to other biological agents besides the endomycorrhizal fungi possibly present in the inoculum (Koslowsky and Boerner, 1989; Paulitz and Linderman, 1991). These biological effects may involve factors such as phosphorus solubilizing microorganisms (AzconAguilar et al, 1986) or plant-growth promoting bacteria (Kloepper et al, 1980).

The grapevine plants showing better growth had lower infection levels, which reinforces the concept that the intensity of infection is a relative parameter (Abbott and Robson, 1978). In fact, a high level of infection may cause a drain of photosynthates (Clapperton and Reid, 1992), which is not compensated for by improved mineral nutrition of the host plant. This is illustrated in some of the data obtained with pineapple plants in the acid soil. For example, increases in the intensity of infection and arbuscule frequency of Queen Tahiti and Smooth Cayenne varieties were linked to decrease in plant growth, especially leaf area. Koide (1985) found that shoot parameters in sunflower were affected by the energy sink represented by formation of endomycorrhiza. The optimal level of infection depends on the efficiency and turnover of the different factors involved, such as photosynthetic rates, fungal transport and transfer systems, etc. The present experiments underline the complexity of these interactions since the effects on pineapple plant growth following an increase in fungal infection varied both with the plant variety and the fungal isolate.

These observations illustrate the necessity of considering plant performance as the essential aspect when evaluating inocula or inoculant products. Furthermore, mycorrhizal efficiency has to be considered within a well-defined set of conditions : it is dependent on the plant species or variety, the efficiency of the fungal isolate as well as the adaptability of the inocula to different soil conditions. Pineapple, for example, is a plant which grows better in acid than in alkaline soils (Guillemin et al, 1991), but in the present work it became clear that the fungal inoculants also behaved differently depending on the test conditions. In the alkaline soil, the AGC inoculant was 
consistently superior to the Phytotec inoculant in promoting plant growth and root infection. However, in the acid soil, where the pineapple plants generally grew better, these differences were less evident and lower values occurred in infection parameters than in the alkaline soil.

The greater ability of the Glomus sp (LPA21) strain to promote pineapple plant growth in the acid soil in comparison to both commercial inocula may be explained by the fact that this isolate is from an acid soil and is therefore better adapted to such conditions. Koslowsky and Boerner (1989) have also reported that an isolate from a strongly acid soil is more efficient under such conditions than one from neutral soil. The commercial inocula are in principle formulated to face a wide range of soil conditions, but the data obtained in the present study suggest that they consist predominantly of isolates which perform better at neutral $\mathrm{pH}$.

The development of an AM fungal inoculant which performs well in a wide range of plants and soil conditions is an ideal target, but this has to be attained in a realistic manner. In the present study, where inoculants were tested in combinations of different environmental conditions, soils and plant species or varieties, it is evident that limitations exist in their use. However, the results obtained confirm that utilization of commercial inoculants is technically feasible, even though further experimentation is necessary to carefully define parameters such as optimal doses to be used, efficiency under different soil conditions, and host specificity in response to the endomycorrhizal fungi used.

\section{ACKNOWLEDGMENTS}

This study was made possible via research grants from the CNPq-RHAE Program, Brazilian Ministry of Science and Technology (PL) and the French Ministry of Research and Technology (JPG). The authors thank Vitropics SA (Montpellier, France) for supplying the pineapple microplants, AGC and Phytotec for supplying the inoculants and $V$ Gianinazzi-Pearson for valuable discussions and revision of the manuscript.

\section{REFERENCES}

Abbott LK, Robson AD (1978) Growth of subterranean clover in relation to formation of endomycorrhizas by introduced and indigenous fungi in a field soil. New Phytol 81, 575-585
Azcon-Aguilar C, Gianinazzi-Pearson V, Fardeau JC, Gianinazzi S (1986) Effect of vesicular-arbuscular mycorrhizal fungi and phosphate-solubilizing bacteria on growth and nutrition of soybean in a neutralcalcareous soil amended with $32 \mathrm{P}-45 \mathrm{Ca}$-tricalcium phosphate. Plant Soil 96, 3-15

Blal B, Gianinazzi-Pearson V (1989) Interest of mycorrhiza for the production of micropropagated oil palm clones. Agric Ecosystems Environ 29, 39-43

Carre M, Martin-Tanguy J, Mussillon P, Martin C (1979) La culture de méristèmes et la multiplication végétative in vitro au service de la pépinière. $P u b l$ INRA ANPPF INVUELEC. Petits fruits 14, 8-65

Clapperton MJ, Reid DM (1992) A relationship between plant growth and increasing VA mycorrhizal inoculum density. New Phytol 120, 227-234

Gianinazzi S, Gianinazzi-Pearson V, Trouvelot A (1982) Les Mycorrhizes, Partie Intégrante de la Plante Biologie et Perspectives d'Utilisation. Coll INRA 13, INRA, Paris

Gianinazzi S, Gianinazzi-Pearson V, Trouvelot A (1990a) Potentialities and procedures for the use of endomycorrhizas with emphasis on high value crops. In: Biotechnology of Fungi for Improving Plant Growth (Whips J, Lumsden B, eds) Cambridge Univ Press, Cambridge, 41-54

Gianinazzi S, Trouvelot A, Gianinazzi-Pearson V (1990b) Role and use of mycorrhizas in horticultural crop production. In: 23 IHC Plenary Lectures. Int Soc Hortic Sci, Florence, Italy, 25-30

Guillemin JP, Gianinazzi S, Gianinazzi-Pearson V (1991) L'endomycorrhization de vitroplants d'Ananas comosus : mise en évidence d'un effet mycorhizien. Fruits 46, 355-358

Guillemin JP, Gianinazzi S, Trouvelot A (1992) Screening of VA endomycorrhizal fungi for establishment of micropropagated plants. Agronomie (in press)

Harley JL, Smith SE (1983) Mycorrhizal Symbiosis. Academic Press, London

Hewitt, EJ (1966) Sand and Water Culture Methods Used in the Studies of Plant Nutrition. Tech Comm 22. Commonw Agric Bur, London, 430-434

Hoagland DR, Arnon DI (1950) The water-culture method for growing plants without soil. Circ Calif Agric Exp Stn 347

Kiernan JM, Hendrix JW, Stoltz LP, Maronek DM (1984) Characterisation of strawberry plants produced by tissue culture and infected with specific mycorrhizal fungi. HortSci 19, 883-885

Kloepper JW, Leong J, Teintze M, Schroth MN (1980) Enhanced plant growth by siderophores produced by plant-growth promoting bacteria. Nature 286 , 885-886

Koide $R$ (1985) The nature of growth depression in sunflower caused by vesicular arbuscular mycorrhizal infection. New Phytol 99, 449-462

Koslowsky SD, Boerner RE (1989) Interactive effects of aluminum, phosphorus and mycorrhizae on 
growth and nutrient uptake of Panicum virgatum L (Poaceae). Environ Pollut 61, 107-125

Menge JA (1977) Utilization of mycorrhizal fungi in Citrus nurseries. Proc Int Soc Citricult 1, 129-132

Paulitz TC, Linderman RG (1991) Mycorrhizal interactions with soil organisms. In: Handbook of Applied Mycology (Arora DK, Rai B, Mukerji KG, Knudsen GR, eds) Marcel Dekker, New York, 77-129

Phillips JM, Hayman DS (1970) Improved procedures for clearing roots and staining parasitic and vesicular-arbuscular mycorrhizal fungi for rapid assessment of infection. Trans Br Mycol Soc 55, 158-160

Ravolanirina F, Blal B, Gianinazzi S, GianinazziPearson V (1989) Mise au point d'une méthode rapide d'endomycorhization de vitroplants. Fruits 44,
Sieverding E (1991) Vesicular-Arbuscular Mycorrhiza Management in Tropical Agrosystems. GTZ, Rossdorf, Germany

Trouvelot A, Kough JL, Gianinazzi-Pearson V (1986) Mesure du taux de mycorhization VA d'un système radiculaire. Recherche de méthodes ayant une signification fonctionelle. In: Physiological and Genetical Aspects of Mycorrhizae (Gianinazzi-Pearson V, Gianinazzi S, eus) INRA Press, Paris, 217-221

Wood T (1987) Commercial production of VA mycorrhiza inoculum axenic versus non axenic conditions. In: Mycorrhizae in the Next Decade: Practical Applications and Research Priorities (Sylvia DM, Hung LL, Graham JH, eds) INVAM, Florida Univ, Gainesville, FL, 274 